\title{
An Overview of Geotextiles: Industrial Application in Technical Textiles
}

\author{
Redwanul Hasan* \\ Department of Yarn Engineering, Bangladesh
}

*Corresponding author: Redwanul Hasan, Department of Yarn Engineering, Bangladesh University of Textiles, Tejgaon, Dhaka, Bangladesh.

Received Date: January 08, 2020

Published Date: January 21, 2020

\begin{abstract}
Geotextiles are technical textiles which will lead the future textile market. Geotextiles have great impact on protecting natural disaster. Now a day's countries are very much vulnerable to the influence of climate change. Due to climate change and other causes there are significant number of disasters is happening day by day. Geotextiles can protect our bridges, roads and soil from natural disaster by making embankments and retaining walls. Erosion control can be occurred by this. By using geotextiles, it is made temporary roads or permanent roads. So, at the time of natural disaster it cannot be damaged. The application of geotextiles is huge. Not only disaster time but also the solution of drainage system and reinforcement of road is done by geotextiles. Actually, geotextiles are mixing branch of textile engineering and civil engineering. Civil engineers look after the civil part and textile engineers look after the textile materials of it. Geotextiles are made by various way. But in industrial approach geotextiles are made some different way. In this article it is discussed about all of it. Besides protecting from natural disaster geotextiles can separate the soil. That's why geotextiles are used to identify the soil and soils quality. In this article, it is taken image of the application of geotextiles, how geotextiles can make, how can it protect the natural disaster. This is also discussed about geotextiles history and types. So, it can be said that from this article an overview of geotextiles can be found.
\end{abstract}

Keywords: Geotextiles; Erosion; Reinforcement; Natural fiber; Man- made fiber; Separation; Filtration, Drainage; Geosynthetics; Solid barrier; Surfacing; Tension membrane

\section{Introduction}

The word "Geotextiles " is come from "Geo and "Textiles." Geo means ground or land. It can be soil related term. According to the textile institute the word "Textile" means a general term applied to any manufacture from fibers, filaments or yarns characterized by flexibility, fineness and high ratio of length to thickness" so the "Geotextiles" definition are it is a permeable fabrics which is used in association with soils ability to protect, separate, filter reinforcement and drain .It is made by natural fibers and also manmade fibers. The geotextile fabric can be created by the blending of natural or manmade fibers also. Geotextile composites are very well known and its products such as geogrids and meshes have been developed recently. Geotextiles are very durable, soften and someone fells down of it. Geotextile is also known as geosynthetics, though there is some dissimilarity between its. It is helpful to environmental science to design of environment [1].

\section{History of Geotextiles}

The introduction of geotextiles was established in China and Kerala at this subcontinent. Woven mats made of reeds used in Babylonia which was actually a geotextile. Construction of great wall of China is be like that. In Kerala there is a convention to spread coconut leaves over the sub-grades. Trees stolon's are laid on soft marshy soils to facilitate walking in some developing countries. Now a days many developed countries are using this vegetation technique to control erosion of soil surface to the environmental issues (Figure 1).

The mixing type or blending type of geotextiles were began at 1950's after the invention of polymeric materials. It had been launched only due to the commercial reasons. To overcome the soil related problem the uses of natural ingredients, technologists thought to make fabrics from manmade materials such as polyamide, polyethylene that's requirement to improve soil strength and behavior. The Netherland is the first country to take a plan to make man -made geotextiles. In 1953, she took a massive "Delta" project to save the country from the ravages of floods generated from the North Sea by making man-made geotextiles. Other developed countries like USA started using geotextiles specially prevent from the soil erosion. Around the 1960's the man-made geotextiles were globally popular. Below the countries which are using geotextiles are shown by the Map (Figure 2). 


\section{History}

Geotextiles can be made from either natural or synthetic fibres

The exploitation of the use of natural fibres in construction can be traced back to the

fifth and fourth millennia BC as described in the Bible (Exodus chapter 5, verse 6-9)

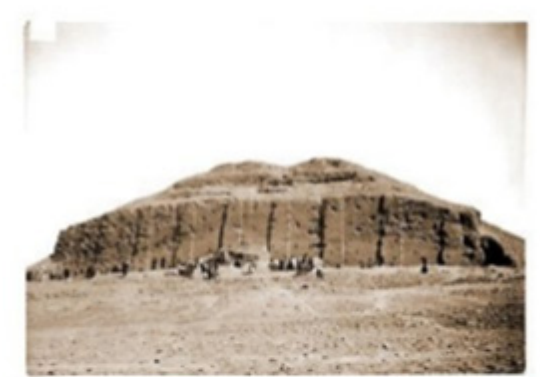

Babylonians 3000 years ago constructed this Ziggurat using reeds in the form of woven mats and plaited ropes as reinforcements

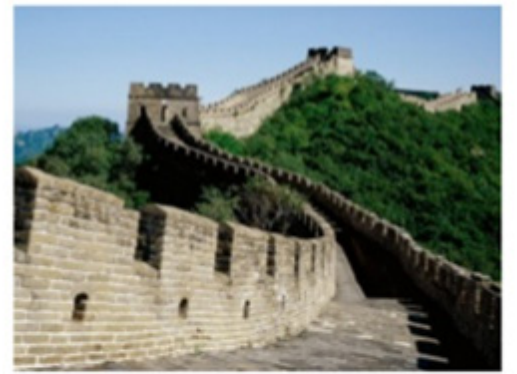

The Great Wall of China, completed circa $200 \mathrm{BC}$, utilised tamarisk branches to reinforce mixtures of clay and gravel

Figure 1: The historical picture about innovation of geotextiles.

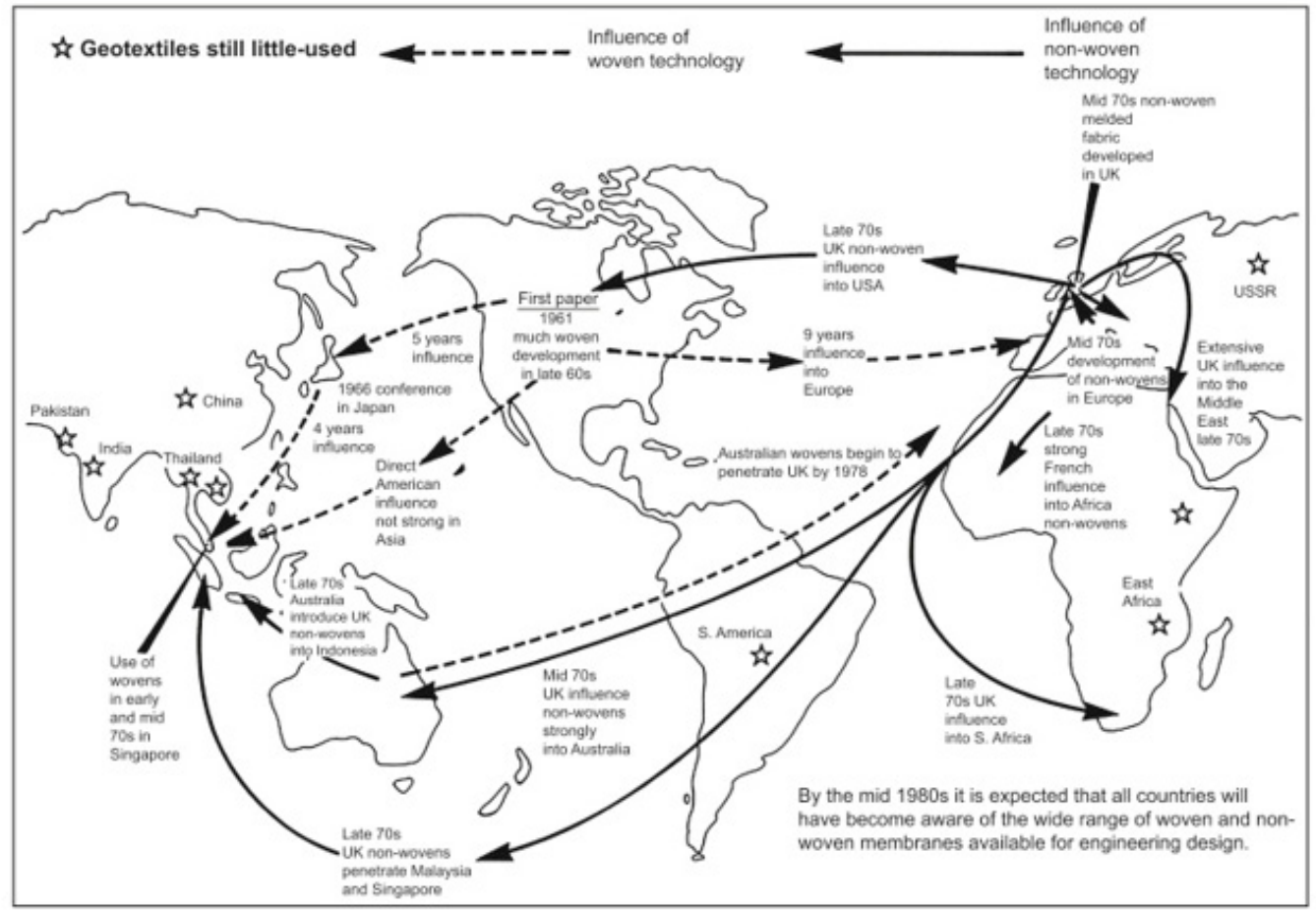

Figure 2: The geographical view of using geotextiles from country to country.

It is cleared from the map, south- Asian regions and African regions lagged behind from using geotextiles as an industrial application, but in UK and USA geotextiles are using very rapidly due to the woven and non-woven technologies [2,3].

\section{Types of Geotextiles}

Geotextiles are divided into mainly two types: Fiber based geotextiles \& Fabric based Geotextiles. Fiber based Geotextiles are discussed below:

\section{Natural fibers}

Natural fibers are collected from plant, animal and mineral origins. The large quantity of these fibers is available worldwide. The natural fibers have some properties to help making geotextiles. They are high strength, high modulus, low breaking extension and low elasticity. Yarn and fabrics produced from natural fibers show low level of creep ability during application. Mineral fibers are brittle and low flexible that's why mineral fibers are not applicable to make geotextiles as an industrial application. The important 
natural fibers which are used in making geotextiles that's are jute, sisal, flax, hemp, abaca, ramie and coir. Geotextiles which are produced from natural fibers they are biodegradable. So, these textile products are used mainly temporary applications. So, the benefits of using natural fibers to make geotextiles are low cost, robustness, strength, durability, availability , good drapeability and biodegradability [4].

\section{Man-made fibers}

The synthetic or man -made fibers are used for geotextiles are called geosynthetics. So, there is a difference between geotextiles and geosynthetics that's are geotextiles are made from both fibers like natural fibers and man -made fibers but geosynthetics are made from only man-made fibers. So, this is said that all geotextiles are not geosynthetics but all geosynthetics are geotextiles. The four polymeric families are recognized as raw materials for geosynthetics they are : polypropylene, polyester, polyamide and polyethylene. The functional characteristics to make geotextiles by the polymeric materials are discussed below:

Polypropylene: Polypropylene is the most used polymer for the manufacturing of geotextiles on account of its low cost , suitable tensile properties and chemical inertness. Polypropylene has low density that's why it has low cost per unit of volume. The disadvantages of polypropylene are it is very much sensitive to UV ray and high temperature. It has poor creep and mineral resistance. Polypropylene should be used under suitable installation and environmental conditions (Figure 3).

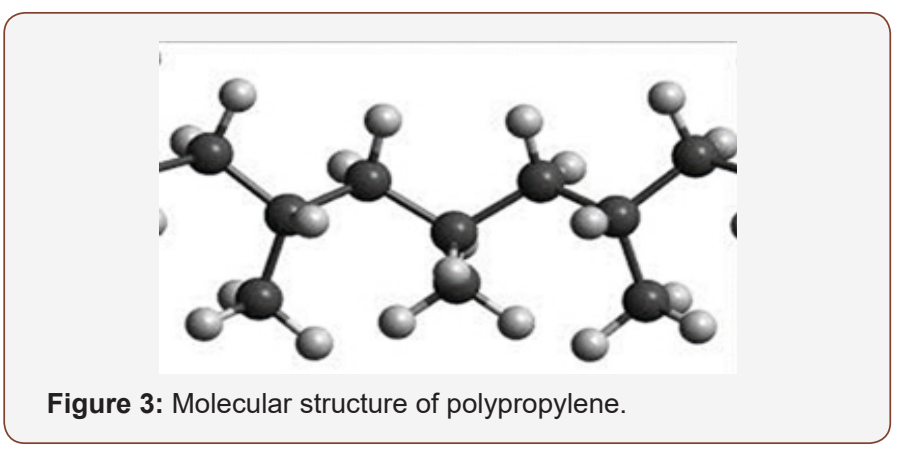

Polyester: Polyester is used as geotextiles because of its superior creep resistance and tenacity values. It is applicable when geotextiles are required high stresses and bluff temperatures. The disadvantage of polyester is hydraulic degradation in soils over the pH10. Polyester fabric is very cheap, and it is found from the PET chips or plastics. The molecular structure of polyester is given below (Figure 4).

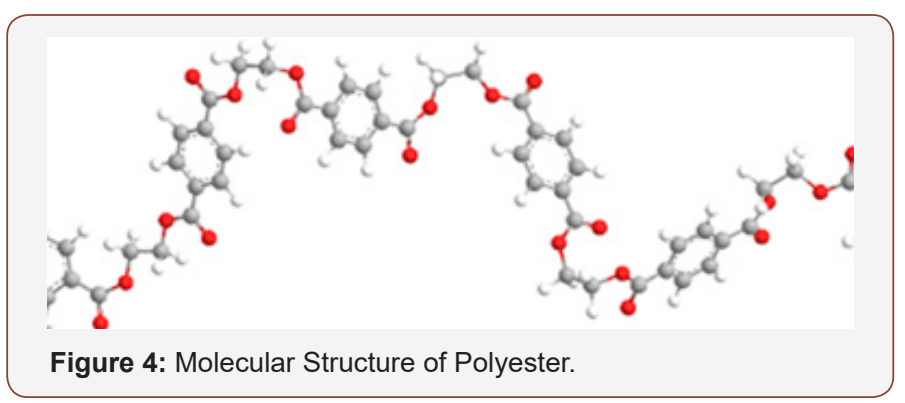

Polyamide: To make traditional geotextiles polyamide is essential .Nylon 6 and Nylon 6:6 are used to make it. Choice of polymers depend on strength, creep behavior, fabric structure \& finishing parameters. The synthetic polyamide is used for it but not natural polyamide like silk, protein is not acceptable for it. Molecular structure of Nylon 6 and Nylon 6:6 is given below (Figure 5 \& 6).

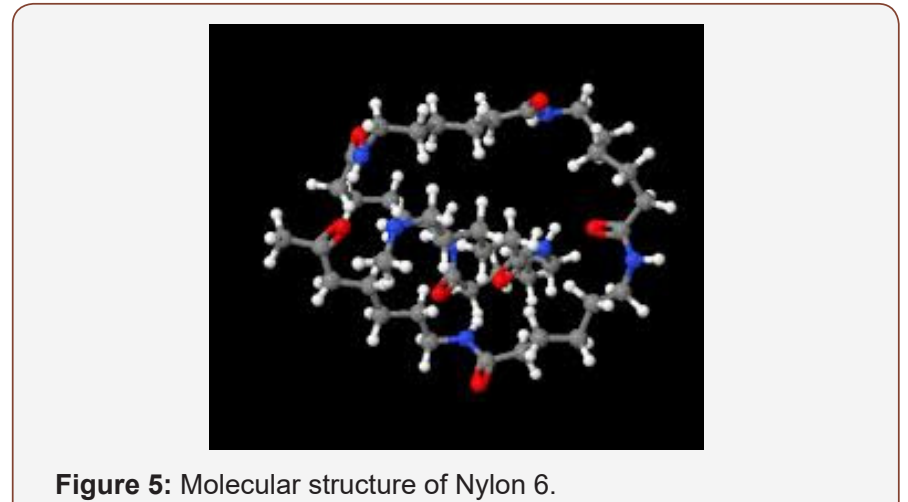

Figure 5: Molecular structure of Nylon 6.

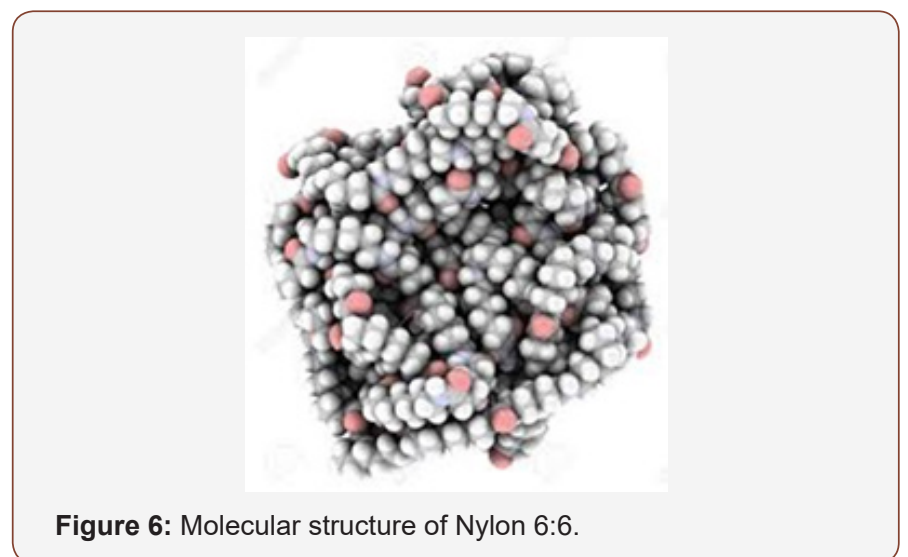

Polyethylene: Polyethylene is used in case of only woven coated geotextiles. The benefits of its uses are minimal thermal expansion and contraction, extra strong resistance provide tear and punctures. It is UV resistant and it has a great heat seaming resistance. The molecular structure of polyethylene is given below (Figure 7).

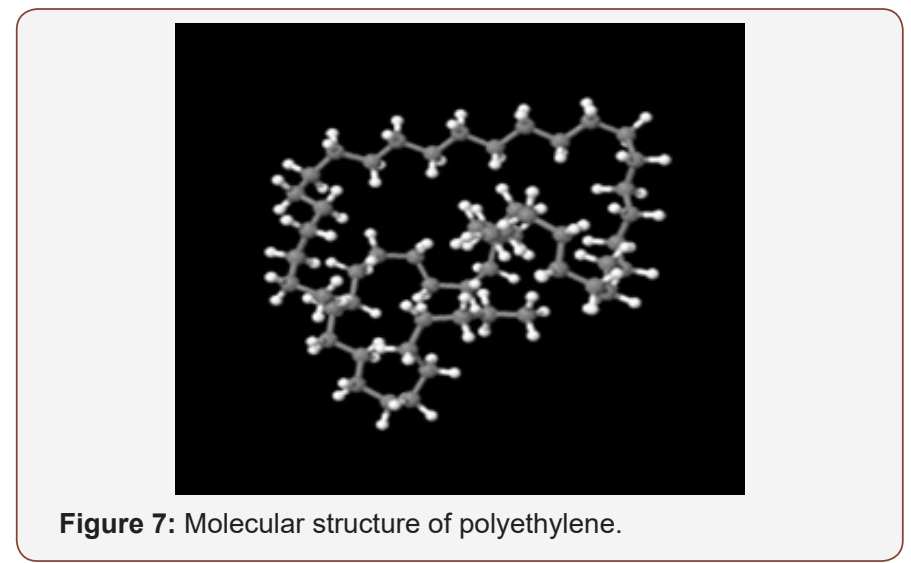

\section{Fabric Based Geotextiles}

There are three types of geotextiles according to fabric . They are: 


\section{Woven geotextiles}

Woven geotextiles are most preferable geotextiles which is used in $70 \%$ cases. Woven geotextiles are textile materials consisting of planar structure by using interweaving of number of threads (both warp and weft). It shows strong mechanical properties. It is divided into two groups: monofilament polyester fabrics and polypropylene based woven geotextiles straps. Its main functions are reinforcement, separation and filtration (Figure 8).

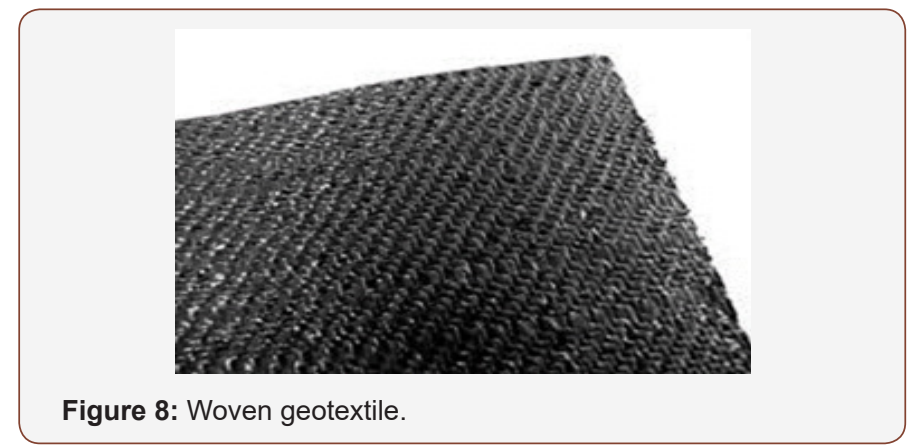

\section{Knitted geotextiles}

Knitted geotextiles are used only $25 \%$ cases. The demand of knitted geotextile is less but it is increasing day by day due to its light weight. For this reason, handling is easier, and cost of transportation is easier. The demand of knitted geotextile is increasing in our Asian subcontinent (Figure 9).

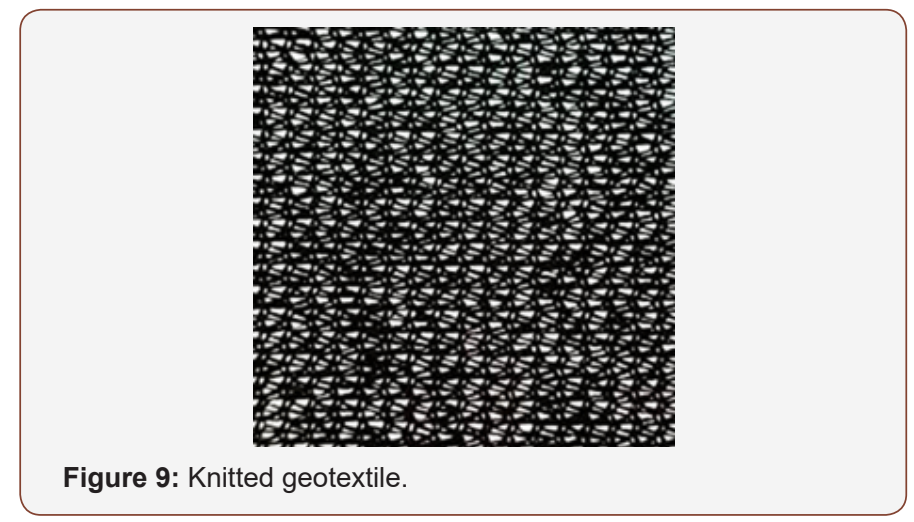

\section{Non-woven geotextile}

Non-woven geotextiles are made from bonding materials together. It is done by chemical or heat, needle punching or other methods. They are mainly made by synthetics fibers. They are used in separation and filter application. They are suitable to use geomembranes lining systems from interior and exterior penetrations. When it is necessary to take pulling water , the nonwoven geotextiles are the best option. Non-woven geotextiles are used only $5 \%$ cases according to its application (Figure 10).

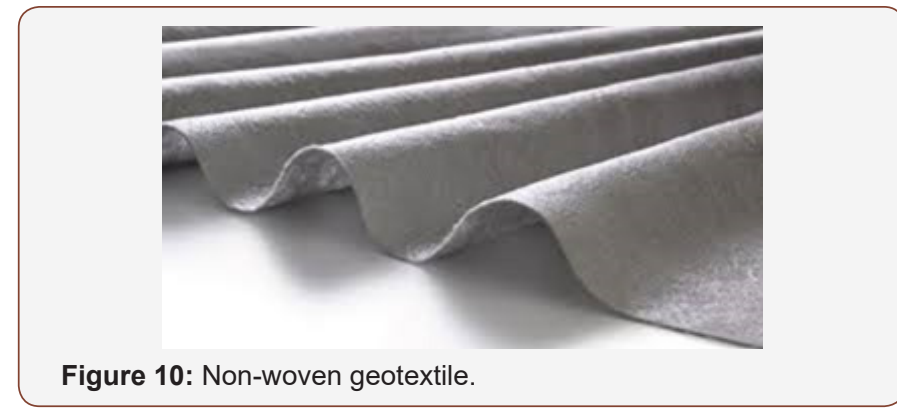

\section{Industrial Process of Making Geotextile}

We know geotextiles are three formed. Woven, Non-woven and knitted. About to industrial process we can understand woven process, because industrially the woven process is followed. Woven fabric is produced by two sets of orthographically interlaced yarn or filament. Woven design pattern is depended on the characteristics of interlacement of yarns. Generally, it is done by three formation . They are Filaments, staple fibers \&Slit films [5,6].

\section{Filaments}

The filaments are manufactured by penetrating molten polymer into spinnerets. This is a conventional process, melt ejection process. The filaments are drawn afterwards according to the molecular orientation along filament. So, filaments gain a high tensile strength and modulus. To increase these mechanical properties, numerous filaments can be occurred through spinnerets and spun. This is called monofilaments.

\section{Staple fibers}

Filaments which is collected from spinnerets in size range of $2-10 \mathrm{~cm}$ is called staple fibers. By twisting they form yarn.

\section{Slit films}

Slit films are produced by sharp blades from melt ejection procedure These films further fibrillated and fragmented, this is called fibrillated yarn.

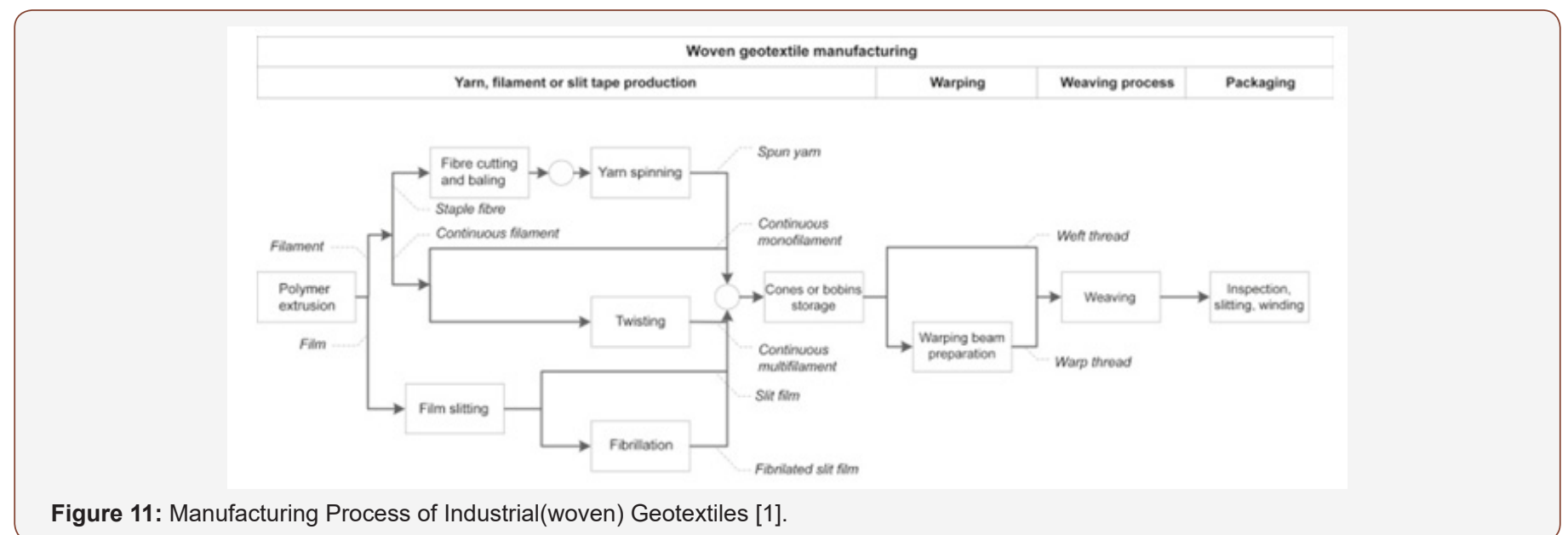


The industrial process of geotextiles is given by a flow chart below (Figure 11).

This is very popular process to make woven geotextiles. Here, filaments or films are first cut or films slitting then after twisting , spinning and fibrillation it takes into various formation. After creating various formation, it takes into bobbin storage and into the warping beam, it makes weaving finally.

\section{Prevention of Natural Disaster}

Geotextiles can prevent natural disaster. It can protect soil erosion, make temporary roads, permanent roads etc. There are three processes to prevent natural disaster. These are discussed below:

\section{Sensors used in geotextiles}

Sensors which are integrated with geotextiles can also be made for monitoring rainstorms, leakage, NPS pollution and water runoff. Fabric sensors have lightweight, flexible and can easily integrated in the fiber structure. Nanoparticles are an arrangement of molecules and atoms that when combined together creates stable building that can be used larger more complex materials and structures. There are various kinds of sensors among them two board categories sensors are used in textiles. They are Fiber optic sensors \& sensing fibers. In fiber optic sensors, an instrument is used name interferometer in which the interference of two beams of light is employed to take precise measurement technique. Extrinsic sensors are used in that case. It is an optical fiber as a means of relaying signals from a remote sensor to the electronics that process the signals. When natural disaster occurs, the textile which was used to as a reinforcing material that creates signal then we conscious about protecting disaster \& save the lives. In case of sensing fibers, nano sensors embedded into the textiles which are very compact \& gives reliable environment in the fabric structure and make possible easy installation of sensors areas. It works by signal system \& it is very helpful to difficult moment of disaster. Its responses quickly (Figures $12 \& 13$ ) [7-9].

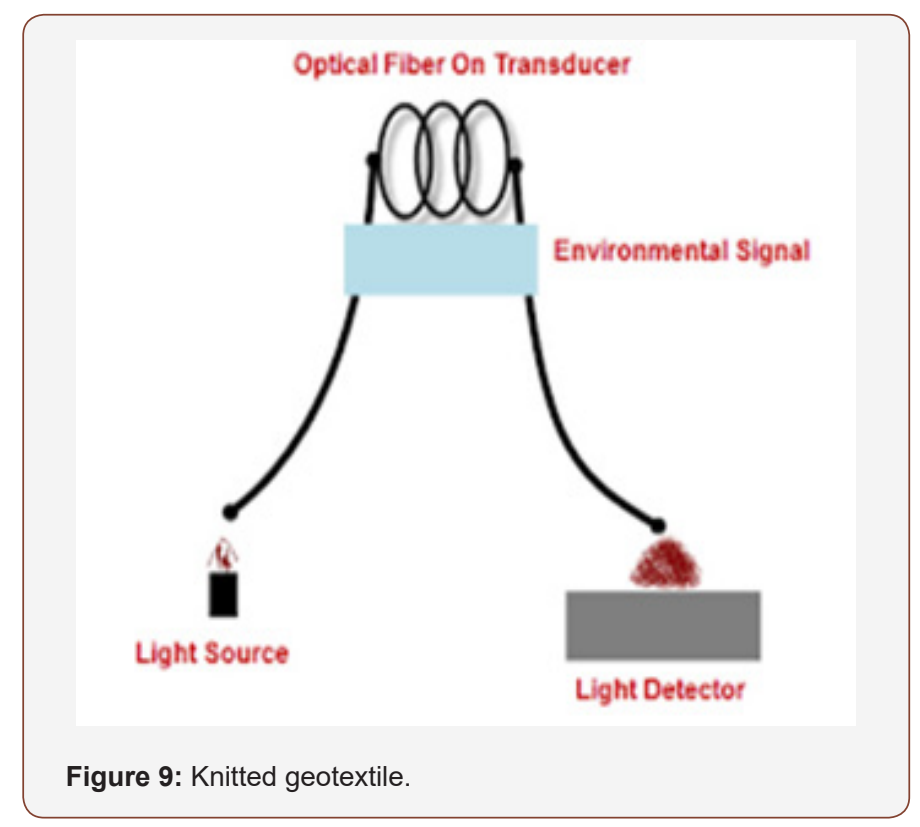

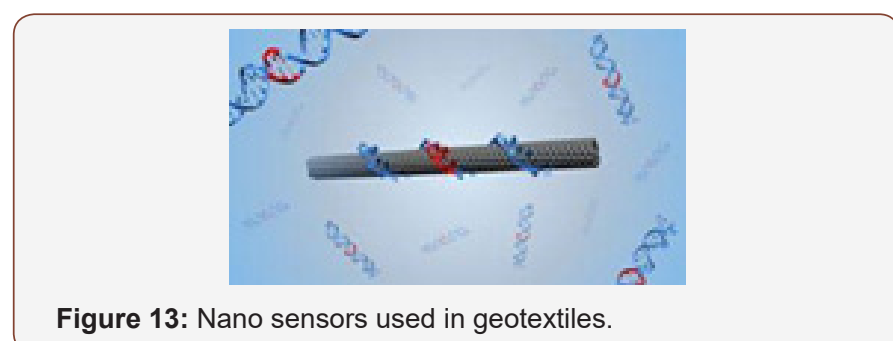

\section{Soil erosion control by geotextiles}

Soil erosion control means protecting the soil from degradation. To protect it, geotextiles application has very good effect. In this process, materials are laid on the surface and bot buried to the soil. The main goals of this process are control erosion \& creating auto process for controlling erosion naturally. The geotextile can fertilize the soil by degradation. Geotextile can intersect the running across the soil \& protect the unvegetated soil from natural force like sun, rain \& wind. Weeds \& plants inhibit it. Erosion control help to protect natural disaster at riverbanks \& coastal areas by creating wave motion from the flow of the tide (Figure 14).

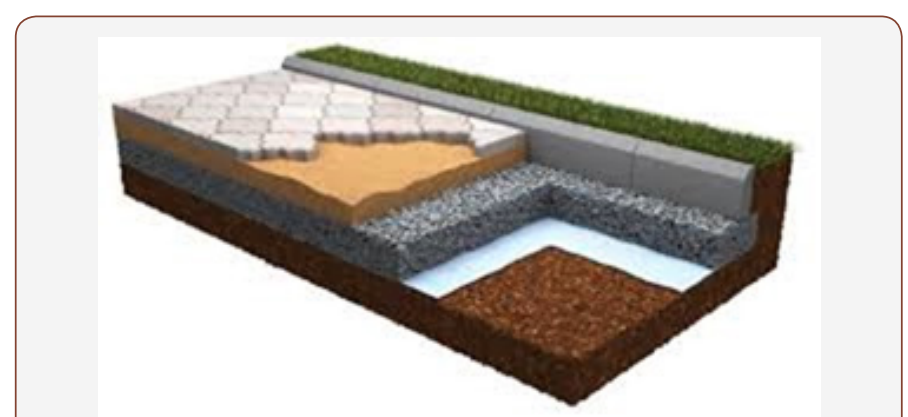

Figure 14: Soil fixation with geotextiles to protect erosion.

\section{Making temporary \& permanent roads with embankments}

Maximum construction site needs to make temporary roads through accessing. Temporary roads are constructed by spreading a carpet of stone metal which is granular form. It has a soft subgrade to act as a load dispersing medium. The continuous movement of vehicles create excessive pressure and granular coating getting lose day by day. The layer of geotextiles make solution it. It keeps thickness of the granular fill \& tensile strength also. Geotextiles are mainly used as a fabrication yard on soft jacket fabrication. A depth of $700 \mathrm{~mm}$ of stone aggregate as soft stone interlacement of geotextiles. This not only allowed a saving of $200 \mathrm{~mm}$ stone filling but enable quick construction of the fabrication yard. This type of roads helps to at the time natural disaster. They protect grass land of coastal areas from the tidal wave (Figure 15).

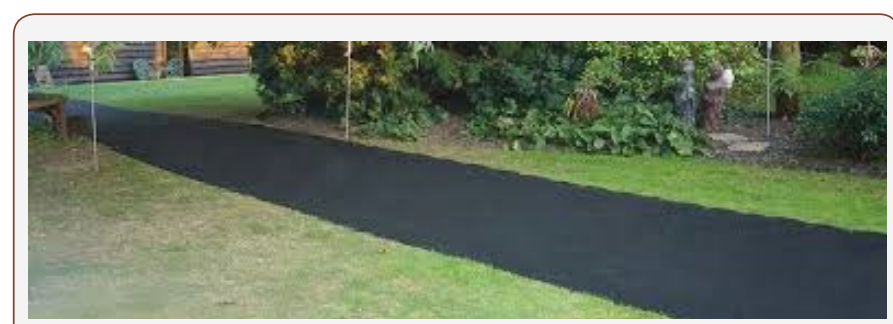

Figure 15: Grass land covered by temporary geotextiles road. 
Permanent roads are made by geotextiles with embankments. In case of flood affected area, geotextiles create permanent protection to destroy roads. For making permanent roads bituminous layer is used. To make embankments geotextiles are filling horizontally. High performance-based geotextiles can be separated the gravels and distribute the loads equally. Non-woven geotextiles are best for making permanent roads (Figure 16).

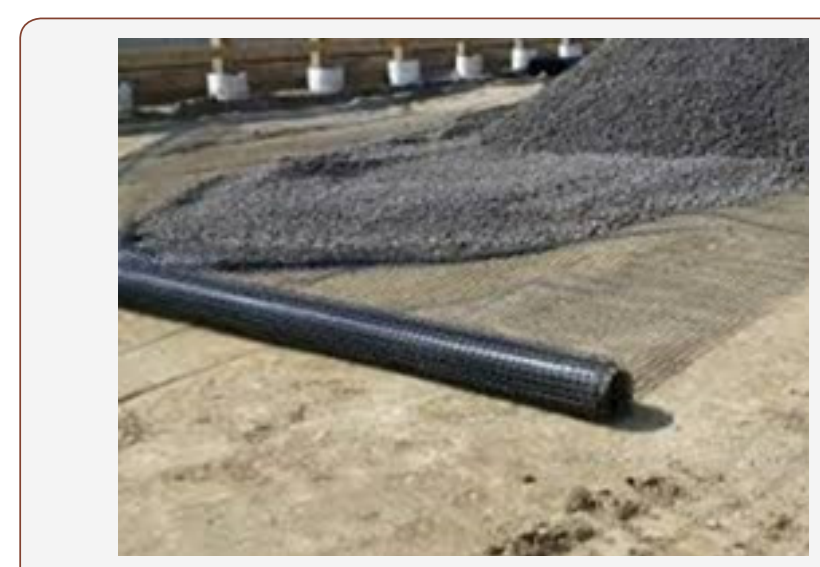

Figure 16: Permanent road by bituminous layer.

\section{Soil Separation \& Identifying Soils Quality}

Soil separation is happened by using geotextiles. In soil, geotextiles are used mainly between two layers. One is coarse layer and another one is fine layers. It preventing pebbles mixing with subgrade and penetrate the barrier. For using between two layers, it helps to reduce contamination of soil. It works as a separator. It mitigates frost effect in soil condition. It carries capillary barriers. The separation or filtration process paves the way to identify soil quality. In atmosphere condition, soil is divided into three categories : temporary, durable and permanent. To experiment it, resin finishing can be applied on the geofabrics. Temporary soil is lasting with geotextile within 7 days and it is not biodegradable. For durable soil, curing is needed for the finished geofabrics for lasting. It is semi -biodegradable. For permanent soil, it is occurred permanently . No curing is needed for this and full biodegradable

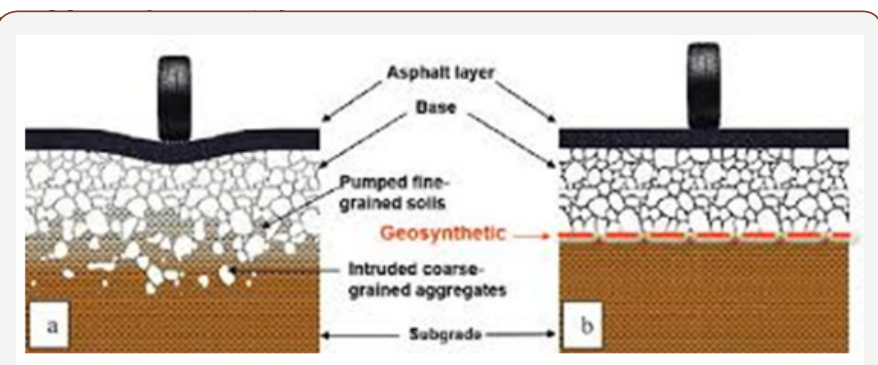

Figure 17: Soil Separation by geosynthetics.

\section{Functional parameters \& Worldwide Consumption}

The functional requirement of geotextile is badly needed for its durability and efficient mechanism . The parameters are (Table 1):

Table 1: Functional requirements for making geofabrics to protect natural disaster.

\begin{tabular}{|c|c|c|c|c|c|}
\hline Properties & Reinforcement & Filtration & Separation & Drainage & Erosion control \\
\hline Tensile strength & Highly important & $\begin{array}{l}\text { Highly important } \\
\text { \&important }\end{array}$ & Important & Not applicable. & Moderately important \\
\hline Elongation & Moderately important & $\begin{array}{l}\text { Highly important \& } \\
\text { important }\end{array}$ & Moderately important. & Moderately important & Highly important \\
\hline Biodegradability & Moderately important & Moderately important & Moderately important & Moderately important & Moderately important \\
\hline Frictional properties & Moderately important & $\begin{array}{l}\text { Highly important } \\
\text { \&important }\end{array}$ & Highly important & Not applicable & Important \\
\hline Resistance to flow & Highly important & Highly important & Highly important & Highly important & Moderately important \\
\hline
\end{tabular}

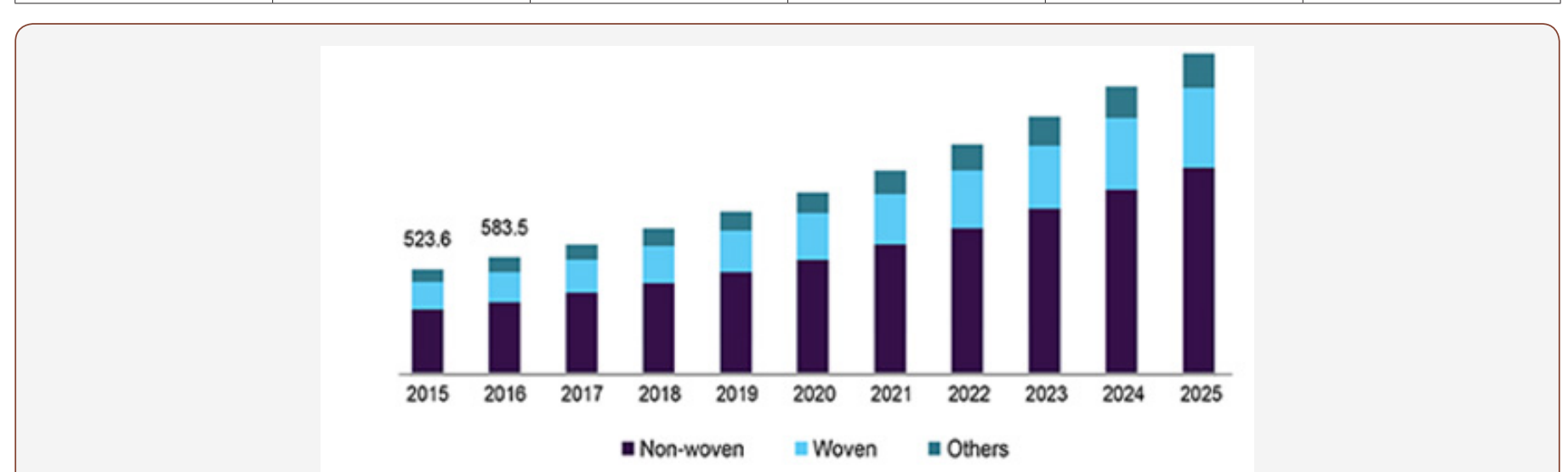

Figure 18: consumption of geotextiles from 2015-2025 [2].

The requirements help to make geomembranes to protect natural disaster. It is helping to produce durable geofabrics. These are basic requirements. Other requirements are interlock, creep, tear resistance, penetration, puncture resistance, permeability, water, properties of soil, chemical resistance, UV light, climate, quality assurance etc. The world climate is changing day by day, the symptom of disaster is changing rapidly. At the time of using sensors \& nano sensors the properties should be checked properly are taken. There is an immense relationship between functional behavior and world consumption of geotextiles. Functional characteristics 
provide betterment to the preventing disaster and worldwide consumption is increasing day by day. mainly European and USA countries are using geotextiles application. Asian region is lagged behind to use it though Asian countries are very much vulnerable to natural disaster. The backward linkage of technical textile knowledge and low opportunity to collaborate with civil engineers are liable for this. It can reduce this distance. All over the world, scientists and engineers are working together from various field. The global geotextile market was valued 4.1 USD billion in 2018 . It will be increased $12.0 \%$ in 2025 due to its increasing demand in drainage and erosion control. Mainly the non-woven geotextiles are dominating the market . it is accounted $66.4 \%$ share in 2018 . Nonwoven geotextile has some special characteristics to increase this demand: High water permeability, absorbency, mechanical strength and liquid repellency. It is mostly used in road constructions. Below the arising position of geotextiles in 2025 from 2015 in shown by graph and the percentage of using geotextiles various fields in shown by pie chart (Figures 18 \& 19) [10].

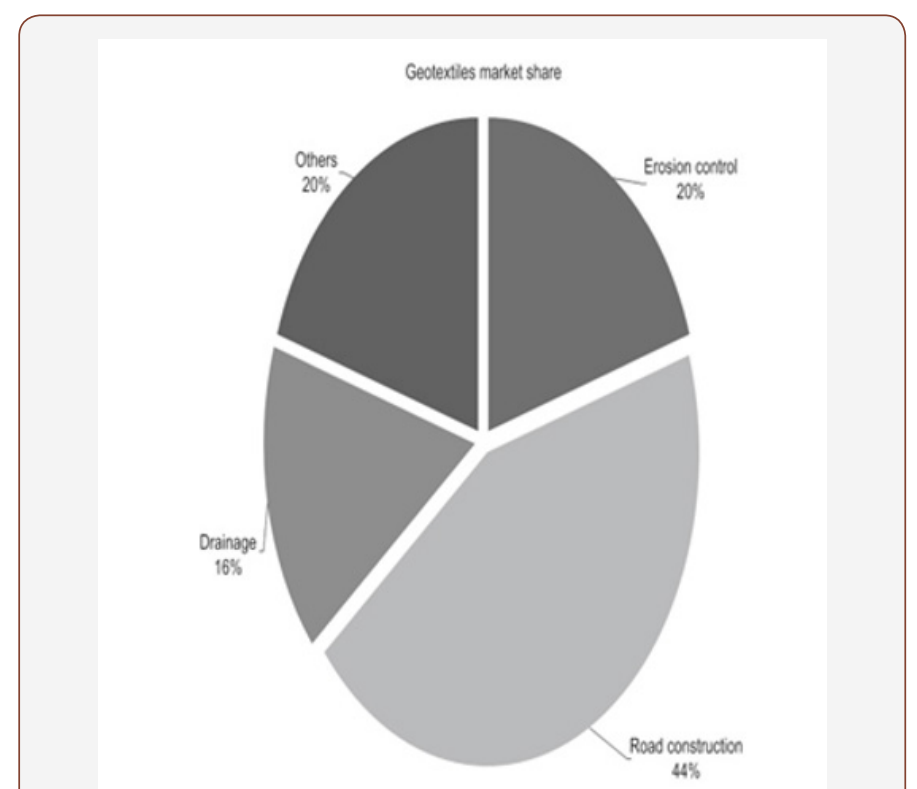

Figure 19: Using percentage of geotextiles.

\section{Conclusion}

The overall idea of geotextile is captured from this article . To prevent natural disaster using geotextile is not a nightmare idea. The developed countries are used to prevent natural disaster, trying to develop textile products and various materials. The climate change is occurring very rapidly, the probability of happening natural disaster is increasing. So, the world wants to make sustainable roads, bridges, embankments that will not be destroyed. Due to functional properties, geotextiles can help for it. The Asian region are lagged behind to do it that has been explained but have to use it. The world geotextile market is increasing. So, it is clearly said that geotextile will grab our future textile market. Besides preventing natural disaster, it is used to make drainage system and filtration. Temporary roads are made by it, so cost is reduced half level of actual cost. In fine, it can be said that Geotextile is a one kind of technical textile, which has immense impact on preventing natural disaster. It also increases surfacing strength of soil layers.

\section{Acknowledgement}

None.

\section{Conflict of Interest}

Author declare no conflict of interest.

\section{References}

1. Berube D, Saunier P (2016) Manufacturing Process of Geotextiles, Geotextiles. ELSEVIER, Woodhead publishing, USA, p. 25-60.

2. Geotextiles Market Size \& Share, industry Analysis Report by Material (PP, PE), by Region, and segment Forecasts, 2019-2025, Market Research Report.

3. Das SC, Paul D, Fahad MM, Islam T, Nizam EH (2017) Geotextiles -A potential Technical Textile Product. Journal of Scientific \& Engineering Research 4(10): 337-350.

4. Nizam EH, Das SC (2014) Geotextile- A Tremendous Invention of Geo technical Engineering. International Journal of Advanced Structures and Geotechnical Engineering 3(3): 221-227.

5. Oberhagemann K, Hossain M (2010) Geotextile bag revetments for large rivers in Bangladesh. Geotextiles and Geomembranes 29(4): 402414.

6. Agrawal BJ (2015) Geotextiles: Its Application to Civil Engineering - Overview. National Conference on Recent Trends in Engineering \& Technology.

7. Nithin S, Rajagopal K, Veeraragavan A (2015) The Use of Natural Geotextiles in Reinforcing the unpaved roads. The $6^{\text {th }}$ International Geotechnical Symposium Disaster Mitigation in Special Geoenvironmental Conditions, Chennai, India.

8. Sharma A (2019) Geotextiles Market, Growth, Share, Global Industry Analysis Report 2018-2025.

9. Alsalmeh KA, Karnoub A, Najjar F, Alsaleh F, Boshi A (2016) Mechanical Properties of Geotextiles After Chemical Aging in the Agricultural Wastewater. Journal of Textile Science \& Engineering 6: 1.

10. Jagany K, Maru A, Prasad K, Goswami P (2017) Natural Disaster Indicators Use of Sensors in Geotextiles. International Journal of Applied Environmental Sciences 12(6): 1083-1100. 